\title{
KURIKULUM 2013 MATA PELAJARAN FIQIH DI MADRASAH TSANAWIYAH (Implementasi, Analisis dan Pengembangannya)
}

\author{
A. Syathori \\ Fakultas Ilmu Tarbiyah dan Keguruan \\ Institut Agama Islam Negeri Syekh Nurjati Cirebon \\ email: asyathori@gmail.com
}

\begin{abstract}
Pada kurikulum Madrasah Tsanawiyah kegiatan pembelajaran mata pelajaran Fiqh pada kelas VII sampai VIII dilaksanakan melalui pendekatan tematik, sedangkan pada kelas IX kegiatan pembelajaran dilaksanakan melalui pendekatan mata pelajaran. Alokasi waktu dalam mata pelajaran Fiqh Madrasah Tsanawiyah adalah 2 jam pembelajaran, dengan alokasi waktu 40 menit setiap kegiatan pembelajaran. Secara substansial mata pelajaran Fiqh memiliki konstribusi dalam memberikan motivasi kepada peserta didik untuk mempraktekkan dan menerapkan hukum Islam dalam kehidupan sehari-hari sebagai perwujudan keserasian, keselarasan dan keseimbangan hubungan manusia dan Allah, dengan diri manusia itu sendiri, sesama manusia, makhluk lainnya ataupun lingkungannya.

Untuk mengembangkan indikator pembelajaran setiap guru seharusnya berpedoman pada Taksonomi Bloom karena di dalam taksonomi Bloom tersebut levellevel ranah kemampuan baik itu kemampuan kognitif, afektif maupun kemampuan psikomotor sudah tersusun secara sistematis dan terdapat banyak pilihaan kosa kata yang sesuai dengan tuntutan KI-KD. Hal ini menjadi suatu tuntutan yang harus dipenuhi oleh seorang guru karena diantara prinsip pengembangan silabus adalah sistematis, relevan dan memadai.

Agar seorang guru yang mengajar dapat mengevaluasi pembelajaran yang sesuai dengan keadaan siswa, media, sarana dan prasarana serta lingkungan sekolahnya, maka seorang guru harus melakukan metode evaluasi pembelajaran yang bervariasi.
\end{abstract}

Kata Kunci: Kurikulum 2013, Mata Pelajaran Fiqih, Implementasi 


\section{A. Pendahuluan}

Kurikulum 2013 berusaha untuk lebih menanamkan nilai-nilai yang tercermin pada sikap dapat berbanding lurus dengan ketrampilan yang diperoleh peserta didik melalui pengetahuan dibangku sekolah. ${ }^{1}$

Pembelajaran Fiqih diarahkan untuk mengantarkan peserta didik dapat memahami pokok-pokok hukum Islam dan tata cara pelaksanaannya untuk diaplikasikankan dalam kehidupan sehari-hari sehingga menjadi muslim yang selalu taat menjalankan syariat Islam secara sempurna (kaffah). ${ }^{2}$

Menurut Hamzah B.Uno pembelajaran (learning) adalah suatu kegiatan yang berupaya membelajarkan siswa secara terintegrasi dengan memperhitunkan factor lingkungan belajarnya, karakteristik siswa, karakteristik bidang studi serta berbagai strategi pembelajaran baik penyampaian, pengelolaan maupun pengorganisasian pembelajaran. $^{3}$

Pembelajaran fiqh di Madrasah Tsanawiyah bertujuan untuk membekali peserta didik agar dapat ${ }^{4}$ :

a) Mengtahuhui dan memahami pokok-pokok hokum Islam dalam mengatur ketentuan dan tata cara menjalankan hubungan manusia dengan sesame yang diatur dalam fiqh muamalah.

b) Melaksanakan dan mengamalkan ketentuan hokum Islam dengan benar dalam melaksanakan ibadah kepada Allah dan ibadah social.

Pengembangan Isi kurikulum Fiqh di madrasah Tsanawiyah (MTs) merupakan kelanjutan dari kurikulum di MI, beberapa isi kurikulum merupakan perluasan dan pendalaman dari kurikulum sebelumnya. Dalam hal ini pendidik diharapkan dapat mengembangkan metode pembelajaran sesuai dengan standar kompetensi dan kompetensi dasar, sehingga peran semua unsur sekolah, orang tua siswa dan masyarakat sangat penting dalam mendukung keberhasilan pencapaian tujuan tersebut.

Kompetensi Inti dan Kompetensi Dasar merupakan kurikulum hasil refleksi, pemikiran dan pengkajian dari kurikulum yang telah berlaku sebelumnya. Kurikilum baru ini diharapkan dapat membantu mempersiapkan peserta didik menghadapi tantangan di masa depan. Standar kompetensi dan kompetensi dasar diarahkan untuk memberikan keterampilan dan keahlian bertahan hidup dalam kondisi yang penuh dengan berbagai perubahan, persaingan, ketidakpastian dan kerumitan dalam kehidupan. Kurikulum ini diciptakan untuk menghasilkan out put yang kompeten, cerdas dalam membangun integritas sosial, bertanggung jawab, serta mewujudkan karakter cerminan bangsa dalam pergaulan dunia ${ }^{5}$.

${ }^{1}$ E, Mulyasa, Guru dalam Implementasi Kurukulum 2013 (Bangdung: PT Remaja Rosdakarya Offset,2014), hal. 19

${ }^{2}$ Peraturan Menteri Agama Republik Indonesia Nomor 2 Tahun 2008 Tentang Standar Kompetensi Lulusan Dan Standar Isi Pendidikan Agama Islam Dan Bahasa Ara Di Madrasah hal 51

5.

${ }^{3}$ Hamzah B. Uno, Orientasi dalam Psikologi Pembelajaran (Jakarta:PT Bumi Aksara, 2006. Hal

${ }^{4}$ Peraturan Menteri Agama Republik Indonesia Nomor 000912 tahun 2013 tentang Kurikulum 2013 Mata Pelajaran PAI dan B.Arab, hal 43-44

${ }^{5}$ Peraturan Menteri Agama Republik Indonesia Nomor 54 Tahun 2013 Tentang Standar Kompetensi Lulusan Pendidikan dasar Dan Menengah hal 3 
Dalam implementasi Standar Kompetensi dan Kompetensi Dasar, telah dilakukan berbagai studi yang mengarahkan pada peningkatan efisiensi dan efektivitas layanandan pengembangan sebagai konsekuensi dari suatu inovasi pendidikan. Sebagai salah satu bentuk efisiensi dan efektivitas implementasi kurikulum dikembangkan berbagai model implementasi kurikulum.

Pada kurikulum Madrasah Tsanawiyah kegiatan pembelajaran mata pelajaran Fiqh pada kelas VII sampai VIII dilaksanakan melalui pendekatan tematik, sedangkan pada kelas IX kegiatan pembelajaran dilaksanakan melalui pendekatan mata pelajaran. Alokasi waktu dalam mata pelajaran Fiqh Madrasah Tsanawiyah adalah 2 jam pembelajaran, dengan alokasi waktu 40 menit setiap kegiatan pembelajaran. Secara substansial mata pelajaran Fiqh memiliki konstribusi dalam memberikan motivasi kepada peserta didik untuk mempraktekkan dan menerapkan hukum Islam dalam kehidupan sehari- hari sebagai perwujudan keserasian, keselarasan dan keseimbangan hubungan manusia dan Allah, dengan diri manusia itu sendiri, sesama manusia, makhluk lainnya ataupun lingkungannya.

Realitas yang terjadi di lapangan terkait permasalahan kurikulum di sekolah Madrasah, khususnya Madrasah Tsanawiyah menjadi persoalan baru yang menjadi kendala dalam implementasi kurikulum 2013. Hal inilah yang menjadi ketertarikan bagi penulis, sehingga muncul pertanyaaan bagaimana mengkaji kurikulum 2013 pada mata pelajaran Fiqih kelas 7 di Madrasah Tsanawiyah?

\section{B. Implementasi Kurikulum 2013 Mata Pelajaran Fiqih Kelas 7di Madrasah Tsanawiyah}

Pembelajaran sebagai suatu proses kegiatan, terdiri atas tiga fase atau tahapan. Fase-fase proses pembelajaran yang diaksud meliputi: tahap perencanaan, tahap pelaksanaan, dan tahap evaluasi. Adapun dari kegiatan ini akan dibahas sebagai berikut.

1) Tahap Perencanaan Perencanaan merupakan proses penyusunan sesuatu yang akan dilaksanaan untuk mencapai tujuan yang telah ditentukan ${ }^{6}$.

Langkah yang disiapkan dakam pembembelajaran adalah sebagai berikut.

a) Analisis Hari Efektif dan Ananlisis Program Pembembelajaran.

b) Menyusun Silabus

c) Menyusun rencana pembelajaran ${ }^{7}$

2) Tahap Pelaksanan

3) Tahap Evaluas. ${ }^{8}$

Untuk lebih memahami tentang pelaksanaan kurikulum 2013 pada mata pelajaran Fiqih kelas 7 di Madrasah Tsanawiyah, penulis paparkanImplementasi Pembelajaranberikutnya :

\section{a) Kompetensi Inti}

a. Menghargai dan menghayati ajaran agama yang dianutnya.

b. Menghargaidanmenghayatiperilakujujur,disiplin,tanggungjawab, peduli(toleransi,

\footnotetext{
${ }^{6}$ Dede Rosyada, Paradigma Pendidikan Demokratis: sebuah moel pelibatan Masyarakat dalam penyelenggaraan Pemddikan (Jakarta: Kencana, 2004), hal. 112

${ }^{7}$ Ibid, 112

${ }^{8}$ Muhammad Surya, Psikologi Pembelajran dan Pengajaran (Bangdung: Pustaka Bani Quraisy, 2004), hal. 17
} 
gotongroyong),santun, percayadiri,dalamberinteraksisecara

efektifdenganlingkungan sosial dan alam dalam jangkauan pergaulan dan keberadaannya.

c. Memahami pengetahuan (faktual, konseptual, dan prosedural) berdasarkan rasa ingin tahunya tentang ilmu pengetahuan, teknologi, seni, budaya terkait fenomena dan kejadian tampak mata.

d. Mencoba,mengolah,danmenyajidalamranahkonkret(menggunakan,meng urai, merangkai, memodifikasi, dan membuat) dan ranah abstrak (menulis, membaca, menghitung, menggambar, dan mengarang) sesuai dengan yang dipelajari di sekolah dan sumber lain yang sama dalam sudut pandang/teori.

b) Kompetensi Dasar

1. Menghayati hikmah dari salat sunah

2. Mengetahui cara melakukan salat sunah

3. Memahami salat sunah muakkad dan salat sunah gairu muakkad

4. Mensimulasikan salat sunah muakkad dan salat sunah gairu muakkad

c) Indikator Pencapaian Kompetensi

1. Menjelaskan tata cara salat sunah

2. Menjelaskan pengertian salat sunah muakkad

3. Menunjukkan dasar hukum salat sunah

4. Menjelaskan hikmah disyariatkannya salat sunah

5. Menjelaskan jenis salat muakkad sunah

6. Menjelaskan jenis salat sunah ghairu muakkad

7. Mempraktikkan tata cara salat sunah muakkad

d) Tujuan Pembelajaran

Setelah selesai melakukan kegiatan pembelejaran melalui pendekatan saintific dengan metode komperatif, peserta didik dapat:

1. Menjelaskan pengertian salat sunah muakkad

2. Menunjukkan dasar hukum salat sunah

3. Menjelaskan hikmah disyariatkannya salat sunah

4. Menjelaskan jenis salat muakkad sunah

5. Menjelaskan jenis salat sunah ghairu muakkad

6. Mempraktikkan tata cara salat sunah muakkad

e) Materi Ajar

Pengalaman pribadi kehidupan sehari-hari

1. Fakta

Macam-macam salat sunah

2. Konsep

Pengertian salat sunah muakkad dan ghoir muakkad

3. Prinsip

Dasar hukum salat sunah

4. Prosedur

4.1 Tata cara salat sunah muakkad

4.2 Tata cara salat sunah ghoir muakkad 
f) Metode Pembelajaran

1. Pendekatan : Scientific

2. Metode : Inquiry dan komperatif

3. Teknik : Diskusi, Tanya Jawab, Role Play dan demonstrasi

\section{g) Desain Pembelajaran}

\begin{tabular}{|c|c|c|}
\hline Kegiatan & Deskripsi & $\begin{array}{c}\text { Alokasi } \\
\text { Waktu }\end{array}$ \\
\hline Pendahuluan & $\begin{array}{l}\text { A. Orientasi } \\
\text { Siswa memperhatikan gambar contoh kegiatan salat } \\
\text { sunah yang diperlihatkan guru. } \\
\text { B. Apersepsi } \\
\text { Guru dan Siswa mengekspresikan cerita atau pengalaman } \\
\text { yang berkaitan dengan ibadah salat atau yang lain } \\
\text { C. Motivasi } \\
\text { Siswa diberi penjelasan tentang manfaat mempelajari } \\
\text { ketentuan salat sunah yang akan dipelajari } \\
\text { D. Pemberian Acuan } \\
\text { 1) Siswa memperoleh penjelasan dari guru tentang } \\
\text { ketentuan salat sunah muakkad yang akan dipelajari } \\
\text { 2) siswa dibagi ke dalam beberapa kelompok } \\
\text { 3) Siswa menyimak mekanisme pelaksanaan } \\
\text { pembelajaran }\end{array}$ & 10 menit \\
\hline Inti & $\begin{array}{l}\text { Mengamati } \\
\text { 1) Peserta didik mengamati gambar contoh kegiatan } \\
\text { salat sunah muakkad } \\
\text { 2) Menyimak penjelasan guru tentang ketentuan salat } \\
\text { sunah } \\
\text { 3) Mengamati dan membaca ketentuan salat sunah } \\
\text { Mempertanyakan } \\
\text { 4) Peserta didik bertanya jawab tentang pengertian } \\
\text { salat sunah dan macam-macam salat sunah. } \\
\text { 5) Peserta didik berdiskusi tentang pengertian salat } \\
\text { sunah muakkad } \\
\text { 6) Peserta didik berdiskusi tentang jenis-jenis salat } \\
\text { sunah muakkad } \\
\text { Mengeksplorasi } \\
\text { 7) Peserta didik mengidentifikasi dasar hukum salat } \\
\text { sunah } \\
\text { 8) Peserta didik mengidentifikasi ketentuan salat sunah } \\
\text { muakkad } \\
\text { 9) Peserta didik mengidentifikasi macam-macam } \\
\text { tatacara salat sunah muakkad } \\
\text { Mengasosiasikan } \\
\text { 10) Peserta didik menyimpulkan pengertian salat sunah } \\
\text { muakkad }\end{array}$ & 60 menit \\
\hline
\end{tabular}




\begin{tabular}{l} 
No Hari Salat Sunah \\
\hline 11) Peserta didik menghafalkan dasar hukum salat \\
sunah \\
12) Peserta didik menuliskan tata cara dari berbagai \\
jenis salat sunah muakkad \\
Mengkomunikasikan \\
13) Peserta didik menjelaskan pengertian salat salat \\
sunah sunah \\
14) Peserta didik menjelaskan pengertian salat sunah sunah \\
muakkad \\
15) Peserta didik menyebutkan dasar hukum salat sunah \\
16) Peserta didik menjelaskan tata cara berbagai jenis \\
salat sunah muakkad \\
17) Guru memotivasi siswa supaya membiasakan diri \\
untuk melakukan salat sunah. \\
1) Guru membuat simpulan tentang materi ajar. \\
2) Guru mengadakan evaluasi. \\
3) Guru menugaskan peserta didik mecari keterangan \\
tentang salat sunah muakkad dari berbagai sumber \\
(buku, majalah, internet, narasumber) sebagai 10 menit \\
refleksi. \\
4) Guru menyebutkan materi pelajaran yang akan \\
dipelajari selanjutnya. \\
5) Bersama-sama menutup pembelajaran dengan do'a \\
dan salam.
\end{tabular}

\section{h) Alat dan Sumber Belajar}

Media:

1. Diri Anak

2. Audio/visual

3. Gambar contoh tata cara salat salat sunah

Sumber:

1. Buku paket Fiqih kls VII

2. Kitab kifayatul akhyar bab salat

\section{i) Penilaian}

1. Jenis/teknik penilaian
a. Kompetensi Sikap: Observasi
b. Kompetensi Pengetahuan: Tes Tulis
c. Kompetensi Keterampilan: Unjuk Kerja

2. Bentuk Instrumen :

a. Kompetensi Sikap:

Lembar Penilaian Sikap Diri

Perintah: Berilah tanda centang (v) pada jenis salat sunah yang kamu kerjakan, seperti salat Tahajud, salat Witir, salat Duha dan salat Tahiyatul Masjid! 


\begin{tabular}{|c|c|c|c|c|}
\hline & Tahajud & Witir & Duha & $\begin{array}{c}\text { Tahiyyatul } \\
\text { Masjid }\end{array}$ \\
\hline \multicolumn{5}{|c|}{1} \\
\hline \multicolumn{5}{|c|}{2} \\
\hline \multicolumn{5}{|c|}{3} \\
\hline \multicolumn{5}{|l|}{4} \\
\hline \multicolumn{5}{|l|}{5} \\
\hline \multicolumn{5}{|l|}{6} \\
\hline 7 & & & & \\
\hline
\end{tabular}

Skor nilai:

1) Apabila peserta didik melaksanakan empat salat sunah, skor 4 .

2) Apabila peserta didik melaksanakan tiga salat sunah, skor 3 .

3) Apabila peserta didik melaksanakan dua salat sunah, skor 2.

4) Apabila peserta didik melaksanakan satu salat sunah, skor 1.

Nilai $=\underline{\text { Jumlah nilai skor yang diperoleh } \mathrm{x} 100}$ Jumlah Skor Maksimal

b. Kompetensi Pengetahuan:

Soal Tes Tulis : Soal Pilihan Ganda

Perintah: Berilah tanda (X) pada huruf a, b, c, atau d yang kamu anggap paling tepat!

1. Salat sunah yang hampir selalu dikerjakan Nabi Muhammad Saw. disebut ....
a. salat sunah fardu.
c. salat sunah istimewa.
b. salat sunah muakkad.
d. salat sunah biasa.

2. Salat sunah dikerjakan pada malam hari dengan jumlah rakaat ganjil, paling sedikit satu rakaat disebut ...
a. salat witir.
c. salat istiharah.
b. salat tahajud.
d. salat hajat.

3. Dikatakan salat sunah rawatib muakkad karena Nabi Muhammad Saw....
a. tidak pernah meninggalkannya.
c.hampir tidak pernah meninggalkannya.
b. selalu mengerjakannya.
d. menyuruh untuk Selalu dikerjakan.

4. Salat sunah rawatib ada yang disebut salat sunah rawatib ba'diyah karena dilakukan ....
a. menjelang salat fardhu.
c. sesudah salat fardhu.
b. sebelum salat fardhu.
d. mengiringi salat fardhu.

5. Salat sunah rawatib qabliyah ialah salat sunah yang ... salat fardhu.
a. dilakukan sebelum
c. dilakukan di awal
b. mengiringi dan mengikuti
d. dilakukan sebelum masuk

6. Salat fardu yang tidak boleh diikuti dengan salat sunah rawatib ba' diyah ialah ....
a. salat zuhur
c. salat ashar
b. salat subuh
d. salat subuh dan Ashar

7. Salat sunah yang dikerjakan pada waktu matahari terbit setinggi tombak sampai menjelang waktu Zuhur disebut salat ....
a. duha
c. istisqa
b. istikharah
d. hajat

8. Waktu yang utama melaksanakan salat Tahajud adalah di ....
a. seperdua malam terakhir
c. seperempat malam terakhir
b. sepertiga malam terakhir
d. seperlima malam terakhir

9. Salat Witir dikerjakan sebagai ... salat malam
a. pembuka
c. penengah
b. sisipan
d. awalan 
10. Salat yang dikerjakan karena ingin mendapatkan petunjuk memilih suatu perkara adalah...
a. duha
c. istisqa
b. istiharah
d. hajat

Kunci Jawaban Pilihan ganda:
1. B
2. A
3. B
4. C
5. A
6. D
7. A
8. B
9. D
10. B

Pedoman penskoran:

Nilai $=\underline{\text { Jumlah nilai skor yang diperoleh } \mathrm{x} 100}$

Jumlah skor maksimal

\section{j) Kompetensi Keterampilan:}

Penilaian Unjuk Kerja :

Lembar penilaian praktek salat sunah muakkad dan qasar

\begin{tabular}{|c|c|c|c|c|c|c|}
\hline \multirow[b]{2}{*}{ No } & \multirow[b]{2}{*}{ Nama Siswa } & \multicolumn{4}{|c|}{ Aspek yang Dinilai } & \multirow[b]{2}{*}{$\begin{array}{c}\text { Jumlah } \\
\text { Skor }\end{array}$} \\
\hline & & $\begin{array}{l}\text { Niat } \\
(20)\end{array}$ & $\begin{array}{c}\text { Bacaan/Do'a } \\
(30)\end{array}$ & $\begin{array}{c}\text { Gerakan } \\
(30)\end{array}$ & $\begin{array}{l}\text { Terib } \\
(20)\end{array}$ & \\
\hline 1 & & & & & & \\
\hline 2 & & & & & & \\
\hline 3 & & & & & & \\
\hline
\end{tabular}

\begin{tabular}{lll}
\hline \multirow{2}{*}{ No } & \multicolumn{1}{c}{ Salat Sunah } & $\begin{array}{c}\text { Dilaksanak } \\
\text { an }\end{array}$ \\
\cline { 2 - 3 } & & Ya Tidak \\
\hline 1 & Melaksanakan salat sunah rawatib muakkad dua rakaat sebelum salat zuhur & \\
\hline 2 & Melaksanakan salat sunah rawatib gairu muakkad dua rakaat sebelum salat Zuhur & \\
\hline 3 & Melaksanakan salat sunah rawatib muakkad dua rakaat sesudah salat Zuhur \\
\hline 4 & Melaksanakan salat sunah rawatib gairu muakkad dua rakaat sesudah salat Zuhur & \\
\hline 5 & Melaksanakan salat sunah rawatib gairu muakkad empat rakaat sebelum salat \\
\hline 6 & Ashar & \\
\hline 7 & Melaksanakan salat sunah rawatib gairu muakkad dua rakaat sebelum salat Magrib \\
\hline 8 & Melaksanakan salat sunah rawatib muakkad dua rakaat sesudah salat Magrib \\
\hline 9 & Melaksanakan salat sunah rawatib gairu muakkad dua rakaat sebelum salat Isya \\
\hline 10 & Melaksanakan salat sunah muakkad 2 rakaat sebelum subuh \\
\hline
\end{tabular}

Pedoman penskoran:

Nilai $=\underline{\text { Jumlah nilai skor yang diperoleh } \mathrm{x} 100}$

Jumlah skor maksimal

Tugas :

Isilah table kegiatan berikut ini dengan jujur dan tanggung jawab!

Pedoman penskoran: 
$\begin{array}{ll}\text { Jika jawaban Ya } & =5 \\ \text { Jika jawaban Tidak } & =0\end{array}$

Nilai $=\underline{\text { Jumlah nilai skor yang diperoleh } \mathrm{x} 100}$

Jumlah skor maksimal

\section{Pemetaan Kompetensi DasarMata Pelajaran Fiqih di Madrasah Tsanawiyah}

\section{PEMETAAN KD MATA PELAJARAN FIQIH KELAS 7 TINGKAT MADRASAH TSANAWIYAH}

\begin{tabular}{|c|c|c|c|}
\hline N0 & & KOMPETENSI DASAR & TEMA \\
\hline \multirow{5}{*}{1} & 1.1 & Meyakini ketentuan bersuci dari hadas, najis. & \multirow{5}{*}{ 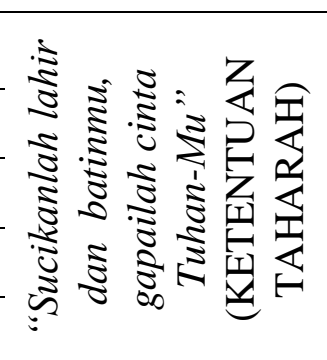 } \\
\hline & 2.1 & Menghayati kaifiah bersuci dari hadas,najis. & \\
\hline & 3.1 & Memahami najis dan tata cara mensucikan & \\
\hline & 4.1 & Menganalisis hadas dan kaifiah mensucikan & \\
\hline & 5.1 & Mendemonstrasikan tatacara bersuci & \\
\hline \multirow{7}{*}{2} & 1.2 & Menghayati ketentuan shalat lima waktu & \multirow{7}{*}{ 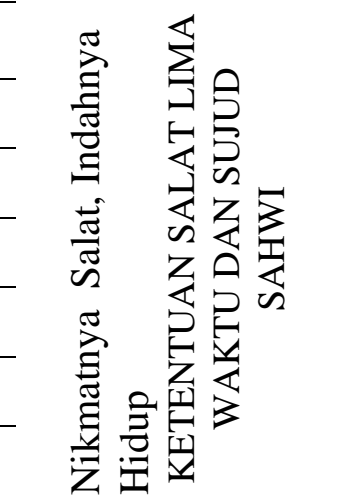 } \\
\hline & 2.2 & Menghayati hikmah shalat lima waktu & \\
\hline & 3.2 & Memahami waktu-waktu shalat lima waktu & \\
\hline & 4.2 & Memahami ketentuan sujud sahwi & \\
\hline & 5.2 & Mempraktikkan azan dan iqamah & \\
\hline & 6.2 & Mempraktikkan shalat lima waktu & \\
\hline & 7.2 & Memperagakan sujud sahwi & \\
\hline \multirow{9}{*}{3} & 1.3 & Meyakini ketentuan shalat berjamaah & \multirow{9}{*}{ 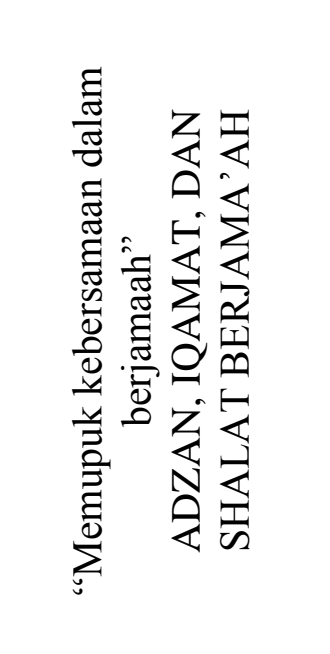 } \\
\hline & 2.3 & Menghayati makna adzan dan iqomah & \\
\hline & 3.3 & Menghayati makna adzan dan iqomah & \\
\hline & 4.3 & $\begin{array}{l}\text { Menghayati nilai-nilai positif dalam shalat } \\
\text { berjamaah }\end{array}$ & \\
\hline & 5.3 & Menghayati makna adzan dan iqomah & \\
\hline & 6.3 & Memahami ketentuan azan dan iqamah & \\
\hline & 7.3 & Menganalisis ketentuan shalat berjamaah & \\
\hline & 8.3 & Mempraktikkan azan dan iqamah & \\
\hline & 9.3 & Mendemonstrasikan tatacara shalat berjama'ah & \\
\hline \multirow{2}{*}{4} & 1.4 & Meyakini kewajiban melaksanakan shalat Jum'at & \multirow{2}{*}{ 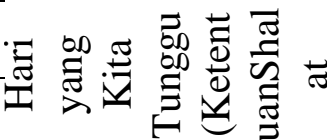 } \\
\hline & 2.4 & Menghayati nilai-nilai positif dalam shalat Jum'at & \\
\hline
\end{tabular}


3.4 Memahami ketentuan shalat jumat

4.4 Menganalisis ketentuan khutbah Jum'at

5.4 Mempraktikkan shalat Jum'at

6.4 Mendemonstrasikan khutbah jumah

1.5 Menerima ketentuan sholat jama'/qoshor

2.5 Meyakini kewajiban shalat dalam berbagai keadaan.

3.5 Menghayati nilai-nilai positif dalam sholat jama' dan qoshor

5

4.5 Menghayati nilai-nilai positif dalam melaksanakan shalat wajib dalam berbagai keadaan

5.5 Memahami ketentuan sholat jama' dan qoshor

6.5 Memahami kaifiat shalat ketika sakit

7.5 Menganalisis kaifiat shalat diatas kendaraan

8.5 Mempraktekan sholat jama' dan qoshor

9.5 Memperagakan shalat dalam keadaan sakit

10.5 Mempraktikkan shalat diatas kendaraan

1.6 Menghayati hikmah dari shalat sunnah

2.6 Menghayati nilai-nilai positif dalam melakukan shalat sunnah

$63.6 \quad$ Memahami ketentuan shalat sunah muakkad

4.6 Menganalisis shalat sunah ghoiru muakkad

5.6 Mempraktikkan shalat sunah muakkad

7.6 Mempraktikkan shalat sunah ghoirumuakkad

PEMETAAN MATA PELAJARAN FIQIH KELAS 8

TINGKAT MADRASAH TSANAWIYAH

\begin{tabular}{|c|c|c|c|}
\hline N0 & & KOMPETENSI DASAR & TEMA \\
\hline \multirow{5}{*}{1} & 1.1 & Menghayati hikmah sujud tilaawah & \multirow{5}{*}{ 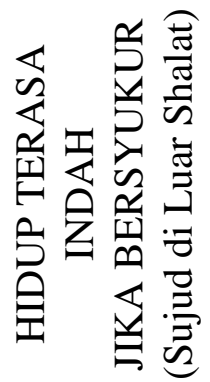 } \\
\hline & 2.1 & Menghayati hikmah syukur & \\
\hline & 3.1 & $\begin{array}{l}\text { Membiasakan sujud tilaawah dalam kehidupan } \\
\text { sehari-hari }\end{array}$ & \\
\hline & 4.1 & Membiasakan sikap bersyukur kepada Allah SWT. & \\
\hline & 5.1 & Memahami ketentuan sujud syukur & \\
\hline
\end{tabular}




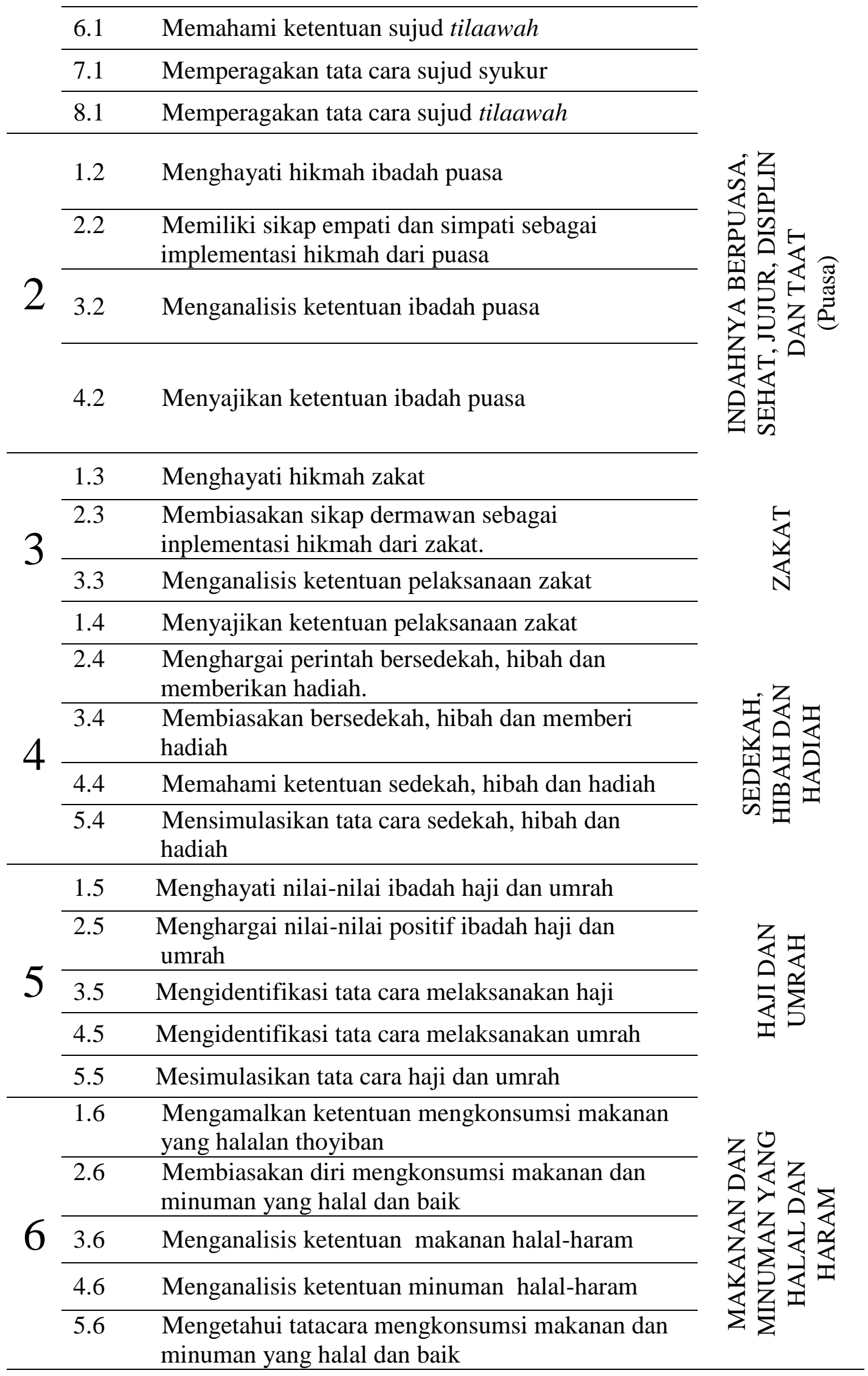


7.6 Mempraktikkan tatacara mengkonsumsi makanan dan minuman yang halal dan baik

\section{PEMETAAN MATA PELAJARAN FIQIH KELAS 9 TINGKAT MADRASAH TSANAWIYAH}

\begin{tabular}{|c|c|c|}
\hline N0 & KOMPETENSI DASAR & TEMA \\
\hline \multirow{7}{*}{1} & 1.1 Menerima perintah berkurban dan akikah & \multirow{7}{*}{ 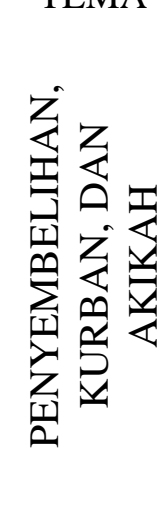 } \\
\hline & 2.1 Menghargai nilai-nilai kurban dan akikah & \\
\hline & 3.1 Memahami kaidah menyembelih binatang & \\
\hline & 4.1 Memahami ketentuan kurban & \\
\hline & 5.1 Memahami ketentuan akikah & \\
\hline & 6.1 Memberi contoh menyembelih kurban & \\
\hline & 7.1 Memberi contoh tatacara pelaksanaan akikah & \\
\hline \multirow{10}{*}{2} & 1.2 Menghayati ketentuan jual beli dalam qiradl & \multirow{10}{*}{ 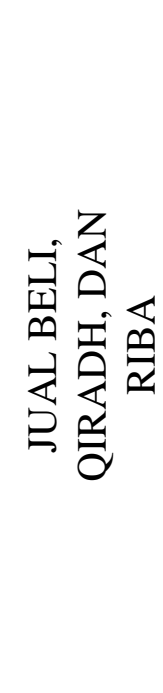 } \\
\hline & 2.2 Menghargai larangan riba dalam jual beli & \\
\hline & 3.2 Mengamalkan ketentuan jual beli dan qiradh & \\
\hline & 4.2 Membiasakan menghindari praktik riba & \\
\hline & 5.2 Memahami ketentuan jual beli & \\
\hline & 6.2 Memahami ketentuan qiradh & \\
\hline & 7.2 Menganalisis larangan riba & \\
\hline & 8.2 Mempraktikkan pelaksanaan jual beli, & \\
\hline & 9.2 Mensimulasikan pelaksanaan qirodl & \\
\hline & 10.2 Mensimulasikan tatacara menghidari riba & \\
\hline \multirow{10}{*}{3} & 1.3 Menghayati ketentuan pinjam meminjam & \multirow{10}{*}{ 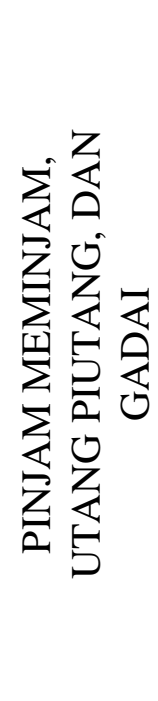 } \\
\hline & 2.3 Menghayati nilai-nilai utang piutang & \\
\hline & 3.3 Menghayati ketentuan gadai & \\
\hline & $\begin{array}{l}\text { 4.3 Mengamalkan ketentuan pinjam meminjam, utang } \\
\text { piutang dan gadai }\end{array}$ & \\
\hline & 5.3 Membiasakan diri memberikan upah sesuai ketentuan & \\
\hline & 6.3 Memahami ketentuan pinjam meminjam & \\
\hline & 7.3 Memahami ketentuan utang piutang & \\
\hline & 8.3 Menganalisis ketentuan gadai & \\
\hline & 9.3 Menjelaskan ketentuan upah & \\
\hline & 10.3 Mempraktikkan tata cara pelaksanaan utang piutang & \\
\hline
\end{tabular}




\begin{tabular}{|c|c|c|}
\hline & $\begin{array}{l}\text { 11.3 Mensimulasikan tatacara gadai } \\
\begin{array}{l}\text { 12.3 } \\
\text { Mensimulasikan tata cara pelaksanaan pemberian } \\
\text { upah }\end{array}\end{array}$ & \\
\hline \multirow{8}{*}{4} & 1.4 Meyakini setiap orang akan mati & \multirow{8}{*}{ 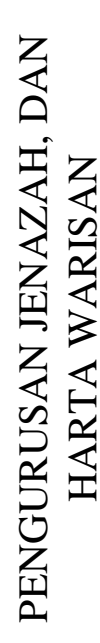 } \\
\hline & 2.4 Menghargai nilai keadilan dalam waris & \\
\hline & 3.4 Menghayat pelajaran penting bertakziah & \\
\hline & 4.4 Membiasakan menegakan ketentuan waris & \\
\hline & $\begin{array}{l}\text { 5.4 Memahami ketentuan pengurusan jenazah, } \\
\text { (memandikan,mengkafani,menshalati, menguburkan) } \\
\text { ta'ziyah dan ziarah kubur }\end{array}$ & \\
\hline & 6.4 Memahami ketentuan waris & \\
\hline & $\begin{array}{l}\text { 7.4 Mendemonstrasikan tata cara memandikan dan } \\
\text { mengkafani jenazah }\end{array}$ & \\
\hline & 8.4 Mendemonstrasikan kaifiah shalat jenazah & \\
\hline
\end{tabular}

\section{b. Pemetaan KI - KDMata Pelajaran Fiqih di Madrasah Tsanawiyah Kelas 7}

\section{Kelas/Semester : VII / 1}

\begin{tabular}{|c|c|}
\hline Kompetensi Inti & Kompetensi Dasar \\
\hline $\begin{array}{l}\text { Menghargai dan } \\
\text { menghayati ajaran } \\
\text { agama yang dianutnya }\end{array}$ & $\begin{array}{l}\text { 1.1. Meyakini pentingnya bersuci dari hadas dan najis } \\
\text { 1.2. Menghayati ketentuan salat lima waktu } \\
\text { 1.3. Menghayati ketentuan waktu salat lima waktu } \\
\text { 1.4. Menghayati makna azan dan ikamah } \\
\text { 1.5. Meyakini ketentuan salat berjamaah } \\
\text { 1.6. Meyakini pentingnya sujud sahwi } \\
\text { 1.7. Meyakini manfaat zikir dan doa }\end{array}$ \\
\hline
\end{tabular}

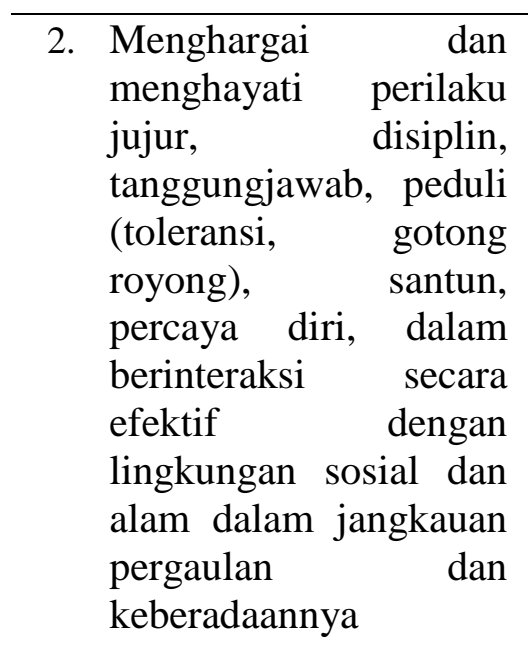

3. Memahami
2.1 Membiasakan diri bersuci dari hadas dan najis

2.2 Membiasakan diri salat lima waktu

2.3 Membiasakan salat tepat waktu

2.4 Membiasakan azan dan ikamah

2.5 Membiasakan diri salat berjamaah

2.6 Terbiasa sujud sahwi apabila ada yang lupa dalam salat

2.7 Senantiasa berzikir dan doa setelah salat

\subsection{Memahami hadas dan najis dan tata cara}




\begin{tabular}{|c|c|c|}
\hline & $\begin{array}{l}\text { pengetahuan (faktual, } \\
\text { konseptual, dan } \\
\text { prosedural) } \\
\text { berdasarkan rasa ingin } \\
\text { tahunya tentang ilmu } \\
\text { pengetahuan, } \\
\text { teknologi, seni, budaya } \\
\text { terkait fenomena dan } \\
\text { kejadian tampak mata }\end{array}$ & $\begin{array}{l}\text { menyucikan } \\
\text { 3.2 Memahami ketentuan salat lima waktu } \\
\text { 3.3 Memahami waktu-waktu salat lima } \\
\text { 3.4 Memahami ketentuan azan dan iqomah } \\
\text { 3.5 Menganalisis ketentuan salat berjamaah } \\
\text { 3.6 Memahami ketentuan sujud sahwi } \\
\text { 3.7. Memahami tatacara berzikir dan berdoa setelah } \\
\text { salat }\end{array}$ \\
\hline 4. & $\begin{array}{l}\text { Mencoba, mengolah, } \\
\text { dan menyaji dalam } \\
\text { ranah konkret } \\
\text { (menggunakan, } \\
\text { mengurai, merangkai, } \\
\text { memodifikasi, dan } \\
\text { membuat) dan ranah } \\
\text { abstrak (menulis, } \\
\text { membaca, menghitung, } \\
\text { menggambar, dan } \\
\text { mengarang) sesuai } \\
\text { dengan yang dipelajari } \\
\text { di sekolah dan sumber } \\
\text { lain yang sama dalam } \\
\text { sudut pandang/teori }\end{array}$ & $\begin{array}{l}\text { 4.1 Mendemonstrasikan tata cara bersuci dari hadas } \\
\text { dan najis } \\
\text { 4.2 Mempraktikkan salat lima waktu } \\
\text { 4.3 Memsimulasikan penentuan salat lima waktu } \\
\text { 4.4 Mempraktikkan azan dan iqomah } \\
\text { 4.5 Mendemonstrasikan tata cara salat berjamaah } \\
\text { 4.6 Memperagakan sujud sahwi }\end{array}$ \\
\hline
\end{tabular}

\section{PEMETAAN KI - KD \\ Kelas/Semester : VII / 2}

Kompetensi Inti

1. Menghargai menghayati agama yang dianutnya ajaran

dan 1.1 Meyakini kewajiban melaksanakan salat Jum'at 1.2 Menerima ketentuan salat Jamak dan Qasar 1.3 Meyakini kewajiban salat dalam berbagai keadaan 1.4 Menghayati hikmah dari salat sunah

2. Menghargai dan menghayati perilaku jujur, disiplin, tanggungjawab, peduli (toleransi, gotong royong), santun, percaya diri, dalam berinteraksi secara efektif dengan lingkungan sosial dan alam dalam jangkauan pergaulan dan keberadaannya
2.1 Membiasakan melaksanakan salat Jum'at

2.2 Membiaskana salat Jamak dan Qasar

2.3 Terbiasa melaksanakan salat wajib dalam berbagai kedaan

2.4 Terbiasa melakukan salat sunah 
3. Memahami pengetahuan konseptual, prosedural) berdasarkan rasa ingin tahunya tentang ilmu pengetahuan, teknologi, seni, budaya terkait fenomena dan kejadian tampak mata

4. Mencoba, mengolah, dan menyaji dalam ranah konkret (menggunakan, mengurai, merangkai, memodifikasi, dan membuat) dan ranah abstrak (menulis, membaca, menghitung, menggambar, dan mengarang) sesuai dengan yang dipelajari di sekolah dan sumber lain yang sama dalam sudut pandang/teori
3.1.Memahami ketentuan salat Jum'at

3.2 Memahami ketentuan salat Jamak dan Qasar

3.3 Memahami kaifiat salat dalam berbagai keadaan

3.4 Memahami salat sunah muakkad dan salat sunah gairu muakkad

4.1. Mempraktikkan salat Jum'at

4.2. Mempraktekan salat Jamak dan Qasar

4.3. Memperagakan salat dalam keadaan sakit

4.4. Memsimulasikan salat sunah muakkad dan salat sunah gairu muakkad

\section{KOMPETNSI INTI DAN KOMPETENSI DASAR}

\section{KELAS VIII SEMESTER GANJIL}

KOMPETENSI INTI KOMPETENSI DASAR

1. Menghargai dan menghayati ajaran 1.1 Menghayati hikmah sujud tilaawah agama yang dianutnya $\quad 1.2$ Menghayati hikmah syukur

1.3 Menghayati hikmah ibadah puasa

1.4 Menghayati hikmah zakat

2. Menghargai dan menghayati 2.1 Membiasakan sujud tilaawah dalam perilaku jujur, disiplin, kehidupan sehari-hari tanggungjawab, peduli (toleransi, 2.2 Membiasakan sikap bersyukur kepada gotong royong), santun, percaya diri, dalam berinteraksi secara efektif dengan lingkungan sosial dan alam dalam jangkauan pergaulan dan keberadaannya

\section{Allah SWT.}

2.3 Memiliki sikap empati dan simpati sebagai implementasi hikmah dari puasa

2.4 Membiasakan sikap dermawan sebagai inplementasi hikmah dari zakat. 


\section{KOMPETENSI INTI}

3. Memahami dan menerapkan 3.1 Memahami ketentuan sujud syukur pengetahuan (faktual, konseptual, 3.2 Memahami ketentuan sujud tilaawah dan prosedural) berdasarkan rasa 3.3 Menganalisis ketentuan ibadah puasa ingin tahunya tentang ilmu 3.4 Menganalisis ketentuan pelaksanaan pengetahuan, teknologi, seni, budaya terkait fenomena dan kejadian tampak mata

\section{KOMPETENSI DASAR}

zakat

\section{Mengolah, menyaji dan menalar 4.1 Memperagakan tata cara sujud syukur dalam ranah konkret 4.2 Memperagakan tata cara sujudtilaawah (menggunakan, mengurai, 4.3 Menyajikan ketentuan ibadah puasa merangkai, memodifikasi, dan 4.4 Menyajikan ketentuan pelaksanaan membuat) dan ranah abstrak zakat}

(menulis, membaca, menghitung, menggambar, dan mengarang) sesuai dengan yang dipelajari di sekolah dan sumber lain yang sama dalam sudut pandang/teori

\section{KELAS VIII SEMESTER GENAP}

\section{KOMPETENSI INTI \\ KOMPETENSI DASAR}

1. Menghargai dan menghayati ajaran agama yang dianutnya

1.1 Menghargai perintah bersedekah, hibah dan memberikan hadiah.

1.2 Menghayati nilai-nilai ibadah haji dan umrah

1.3 Mengamalkan ketentuan mengkonsumsi makanan yang halalan thoyiban

\begin{tabular}{lrr}
\hline 2. Menghargai & dan & menghayati \\
perilaku & jujur, & disiplin,
\end{tabular}
tanggungjawab, peduli (toleransi, gotong royong), santun, percaya diri, dalam berinteraksi secara efektif dengan lingkungan sosial dan alam dalam jangkauan pergaulan dan keberadaannya

$\begin{array}{llll}\text { 3. Memahami dan menerapkan } & 3.1 & \begin{array}{l}\text { Memahami ketentuan sedekah, hibah } \\ \text { pengetahuan (faktual, konseptual, }\end{array} \\ \begin{array}{l}\text { dan prosedural) berdasarkan rasa } \\ \text { ingin tahunya tentang ilmu }\end{array} & 3.2 & \begin{array}{l}\text { Mengidentifikasi tata cara } \\ \text { melaksanakan haji }\end{array} \\ \begin{array}{l}\text { pengetahuan, teknologi, seni, } \\ \text { budaya terkait fenomena dan } \\ \text { kejadian tampak mata }\end{array} & 3.3 & \begin{array}{l}\text { Mengidentifikasi tata cara } \\ \text { melaksanakan umrah } \\ \text { Menganalisis ketentuan makanan } \\ \text { halal-haram } \\ \text { Menganalisis ketentuan minuman } \\ \text { halal-haram } \\ \text { Mengetahui tatacara mengkonsumsi }\end{array} \\ & 3.4 & 3.6\end{array}$




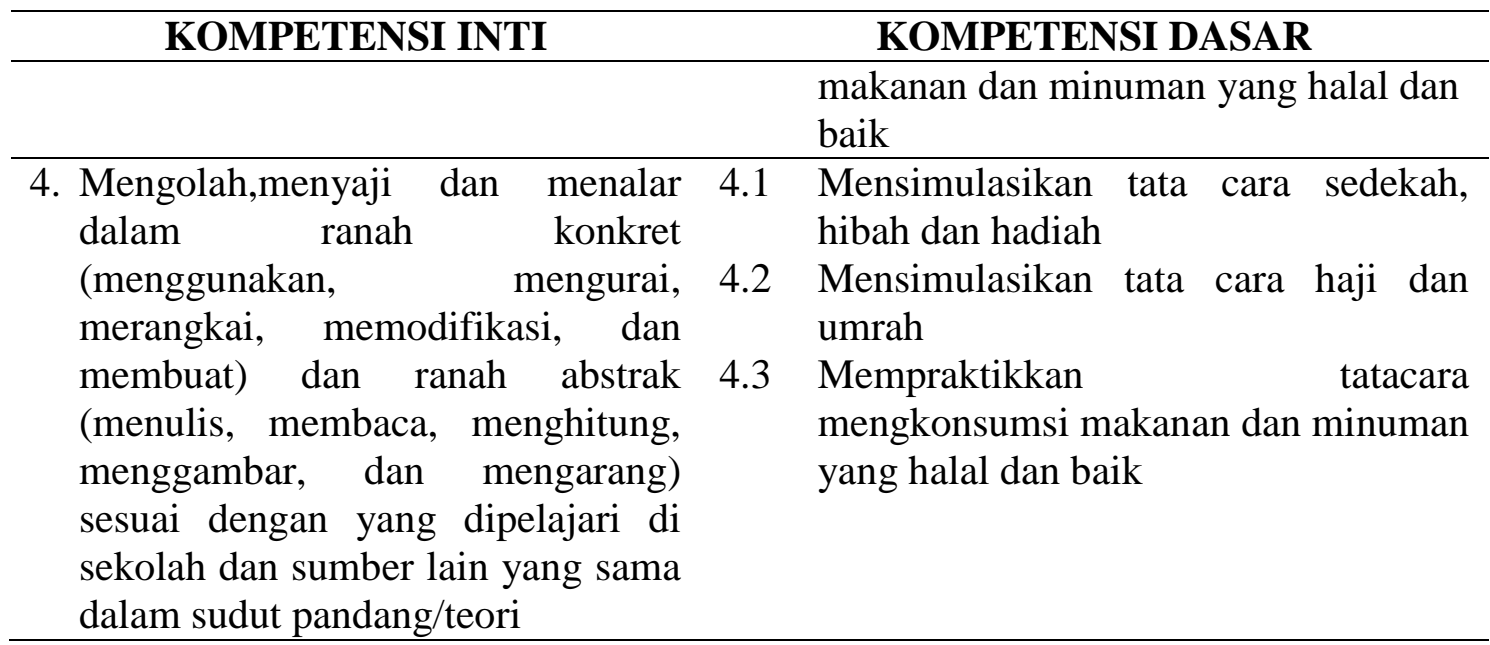

\section{KOMPETNSI INTI DAN KOMPETENSI DASAR}

\section{KELAS IX SEMESTER GANJIL} KOMPETENSI INTI

1. Menghargai dan menghayati ajaran agama yang dianutnya

\section{KOMPETENSI DASAR}

1.1 Menerima perintah berkurban dan akikah

1.2 Menghayati ketentuan jual beli dan qiradl

1.3 Menghargai larangan riba dalam jual beli

2. Menghargai dan menghayati perilaku jujur, disiplin,

2.1 Menghargai nilai-nilai kurban dan akikah

tanggungjawab, peduli (toleransi, gotong royong), santun, percaya diri, dalam berinteraksi secara efektif dengan lingkungan sosial dan alam dalam jangkauan pergaulan dan keberadaannya

3. Memahami dan menerapkan pengetahuan (faktual, konseptual, dan prosedural) berdasarkan rasa ingin tahunya tentang ilmu pengetahuan, teknologi, seni, budaya terkait fenomena dan kejadian tampak mata

2.2 Mengamalkan ketentuan jual beli dan qiradh

2.3 Membiasakan menghindari praktik riba

\begin{tabular}{|c|c|}
\hline 3.1 & $\begin{array}{l}\text { Memahami kaidah menyembelih } \\
\text { binatang }\end{array}$ \\
\hline 3.2 & Memahami ketentuan kurban \\
\hline 3.3 & Memahami ketentuan akikah \\
\hline 3.4 & Memahami ketentuan jual beli \\
\hline 3.5 & Memahami ketentuan qiradh \\
\hline 3.6 & Menganalisis larangan riba \\
\hline 4.1 & Memberi contoh menyembelih kurban \\
\hline 4.2 & $\begin{array}{l}\text { Memberi contoh tatacara pelaksanaan } \\
\text { akikah }\end{array}$ \\
\hline 4.3 & Mempraktikkan pelaksanaan jual beli, \\
\hline 4.4 & Mensimulasikan pelaksanaan qirodl \\
\hline 4.5 & $\begin{array}{l}\text { Mensimulasikan tatacara menghidari } \\
\text { riba }\end{array}$ \\
\hline
\end{tabular}

4. Mengolah,menyaji dan menalar dalam ranah konkret (menggunakan, mengurai, merangkai, memodifikasi, dan membuat) dan ranah abstrak (menulis, membaca, menghitung, menggambar, dan mengarang) 
sesuai dengan yang dipelajari di

sekolah dan sumber lain yang sama

dalam sudut pandang/teori

\section{KELAS IX SEMESTER GENAP}

\section{KOMPETENSI INTI}

1. Menghargai dan menghayati ajaran agama yang dianutnya

\section{KOMPETENSI DASAR}

1.1 Menghayati ketentuan pinjam meminjam

1.2 Menghayati nilai-nilai utang piutang

1.3 Menghayati ketentuan gadai

1.4 Meyakini setiap orang akan mati

1.5 Menghargai nilai keadilan dalam waris

2. Menghargai dan menghayati perilaku jujur, disiplin, tanggungjawab, peduli (toleransi, gotong royong), santun, percaya diri, dalam berinteraksi secara efektif dengan lingkungan sosial dan alam dalam jangkauan pergaulan dan keberadaannya

3. Memahami dan menerapkan pengetahuan (faktual, konseptual, dan prosedural) berdasarkan rasa ingin tahunya tentang ilmu pengetahuan, teknologi, seni, budaya terkait fenomena dan kejadian tampak mata

2.1 Mengamalkan ketentuan pinjam meminjam, utang piutang dan gadai

2.2 Membiasakan diri memberikan upah sesuai ketentuan

2.3 Menghayat pelajaran penting bertakziah

2.4 Membiasakan menegakan ketentuan waris

3.1 Memahami ketentuan pinjam meminjam

3.2 Memahami ketentuan utang piutang

3.3 Menganalisis ketentuan gadai

3.4 Menjelaskan ketentuan upah

3.5 Memahami ketentuan pengurusan jenazah, (memandikan,mengkafani,menshalati, menguburkan) ta'ziyah dan ziarah kubur

3.6 Memahami ketentuan waris

4. Mengolah, menyaji dan menalar dalam ranah konkret (menggunakan, mengurai, merangkai, memodifikasi, dan membuat) dan ranah abstrak (menulis, membaca, menghitung, menggambar, dan mengarang) sesuai dengan yang dipelajari di sekolah dan sumber lain yang sama dalam sudut pandang/teori

\begin{tabular}{|c|c|}
\hline 4.1 & $\begin{array}{l}\text { Mempraktikkan tata cara pelaksanaan } \\
\text { utang piutang }\end{array}$ \\
\hline 4.2 & Mensimulasikan tatacara gadai \\
\hline 4.3 & $\begin{array}{l}\text { Mensimulasikan tata cara pelaksanaan } \\
\text { pemberian upah }\end{array}$ \\
\hline 4.4 & $\begin{array}{l}\text { Mendemonstrasikan tata cara } \\
\text { memandikan dan mengkafani jenazah }\end{array}$ \\
\hline 4. & $\begin{array}{l}\text { Mendemonstrasikan kaifiah shalat } \\
\text { jenazah }\end{array}$ \\
\hline
\end{tabular}




\section{Telaah Kritis Kurikulum Mata Pelajaran Fiqih Di Madrasah Tsanawiyah 1. Pengertian Silabus}

Silabus adalah rancangan pembelajaran yang berisi rencana bahan ajar mata pelajaran tertentu pada jenjang dan kelas tertentu, sebagai hasil dari seleksi, pengelompokan, pengurutan dan penyajian materi kurikulum, yang dipertimbangkan berdasarkan ciri dan kebutuhan daerah setempat. ${ }^{9}$ Ruang lingkup silabus adalah bagian-bagian yang terdapat dalam silabus yang menjadi gambaran umum, bentuk materi yang harus diajarkan kepada peserta didik. Ruang lingkup silabus dijelaskan sebagai berikut: ${ }^{10}$ Kompetensi Inti, Kompetensi Dasar, Materi Pembelajaran, Kegiatan Pembelajaran, Penilaian, Alokasi Waktu, Sumber Belajar ${ }^{11}$

Istilah silabus digunakan untuk menyebut suatu produk pengembangan kurikulum berupa penjabaran lebih lanjut dari KI dan KD yang ingin dicapai, dan materi pokok serta uraian materi yang perlu dipelajari peserta didik dalam rangka mencapai KI dan KD. ${ }^{12}$ Seperti diketahui, dalam pengembangan kurikulum dan pembelajaran, terlebih dahulu perlu ditentukan KD yang berisikan kebulatan pengetahuan, sikap, dan keterampilan yang ingin dicapai, materi yang harus dipelajari, pengalaman belajar yang harus dilakukan, dan sistem evaluasi untuk mengetahui pencapaian KD. Dengan kata lain, pengembangan kurikulum dan pembelajaran menjawab pertanyaan (1) Apa yang akan diajarkan (KI, KD, dan Materi Pembelajaran); (2) Bagaimana cara melaksanakan kegiatan pembelajaran, metode, media); (3) Bagaimana dapat diketahui bahwa KD telah tercapai (indikator dan penilaian).

Silabus adalah rencana pembelajaran pada suatu dan/atau kelompok mata pelajaran/tema tertentu yang mencakup KI, KD, materi pembelajaran, kegiatan pembelajaran, indikator pencapaian kompetensi, penilaian, alokasi waktu, dan sumber belajar.

Silabus bermanfaat sebagai pedoman dalam pengembangan pembelajaran lebih lanjut, seperti pembuatan rencana pembelajaran, pengelolaan kegiatan pembelajaran, dan pengembangan sistem penilaian. Silabus merupakan sumber pokok dalam penyusunan rencana pembelajaran, baik rencana pembelajaran untuk satu KI maupun satu KD.Silabus juga bermanfaat sebagai pedoman untuk merencanakan pengelolaan kegiatan.

Demikian pula, silabus sangat bermanfaat untuk mengembangkan sistem penilaian.Dalam pelaksanaan pembelajaran berbasis kompetensi sistempenilaian selalu mengacu pada KI, KD, dan indikator yang terdapat di dalam silabus.

\section{Analisis Silabus mata pelajaran Fiqih MTs}

Berdasarkan hasil analisis penulis terhadap Silabus yang telah disusun pada mata pelajaran Fiqih tingkat MTs, ada tiga komponen Silabus yang menurut pendapat penulis perlu mendapat perhatian. Adapun tiga komponen Silabus yang perlu mendapat perhatian tersebut adalah sebagai berikut :

9Abdul Majid, Perencanaan Pembelajaran (Bandung: Remaja Rosda Karya, 2008), 39.

10 Fadlilah, Implementasi Kurikulum 2013 dalam Pembelajaran SD/MI, SMP/MTs \& SMA/MA...hal.24

${ }^{11}$ Ibid, hal 92

12 B. Suryosubroto, Proses Belajar Mengajar di Sekolah (Jakarta: Rinneka Cipta, 2009), 45. 


\section{a. Komponen Indikator}

Melalui analisis yang penulis lakukan terhadap silabus yang disusun pada mata pelajaran Fiqih di MTs, khususnya dalam kemampuan mengembangkan indikator, penulis menemukan hal-hal sebagai berikut :

1. Dari seluruh silabus mata pelajaran fiqih pada umumnya masih memilih kata kerja opresional hanya dalam 2 jenis kemampuan yaitu kognitif levelsatu dan kognitif level 2 meskipun untuk kompetensi dasar yang berbeda-beda. Pilihan kata-kata yang digunakan untuk masing-masing kemampuan juga masih sangat terbatas. Untuk kognitif level satu kebanyakan responden hanya menggunakan kata-kata menjelaskan, menyebutkan. Hanya sebagian kecil saja yang sudah mencoba untuk memilih kata-kata selain menyebutkan meskipun belum tentu sesuai dengan kompetensi dasarnya.Begitu juga halnya dengan kemampunan kognitif pada level 2, pada umumnya yang digunakan kata-kata menjelaskan dan menceritakan.Namun kadang sebahagian kecil menggunakan kata-kata lain. Hal di atas ini sebenarnya tidak akan terjadi jika guru mau menggunakan taksonomi Bloom sebagai pedoman di dalam mengembangkan indikator karena di dalam taksonomi Bloom sudah terkoleksi banyak pilhan kata-kata untuk satu level kemampuan yang sesuai dengan tuntutan standard kompetensi maupun tuntutan dari kompetensi dasar.

2. Masih ada penulis temukan dalam mengembangkan indikator belum sistematis atau berurutan. Umpamanya pada indikator pertama memilih kemampuan kognitif level dua yaitu menceritakan tetapi pada indikator ke memilih kemampuan kognitif level satu yaitu menyebutkan. Hal tersebut tentunya sangat bertentangan dengan prinsip pengembangan silabus yaitu prinsip sistematis.

\section{b. Komponen Penilaian}

Dari hasil analisis terhadap Silabus yang ada pada mata pelajaran Fiqih tingkat MTs, penulis menemukan bahwa penilaian yang dicantumkan pada Silabus oleh guru adalah kebanyakan hanya tes tulis saja, dimana tes tulis hanya menilai aspek kognitif siswa, sementara mata pelajaran fiqih sebagai mapel agama sarat dengan praktek. Disini seharusnya guru juga melakukan penilaian dalam aspek afektif dan psikomotorik.Keadaan ini tentu menunjukkan begitu sederhananya wawasan guru di dalam memahami evaluasi pembelajaran.

\section{c.Komponen Kegiatan Pembelajaran}

Kegiatan pembelajaran yang di susun oleh seorang guru dapat dikatakan baik jika kegiatan pembelajaran itu menggambarkan pada langkahlangkah kegiatan yang dilakukan oleh siswa dan guru dimulai dari kegiatan pendahuluan sampai kegiatan penutup sekaligus menunjukkan kepada media pembelajaran yang digunakan di dalam pembelajaran itu.

Mengenai kegiatan pembelajaran yang di susun oleh guru Fiqih di MTs, dalam langkah-langkah pembelajaran sudah menggambarkan pada langkah-langkah kegiatan dari kegiatan pendahuluan sampai pada langkah penutup. Hal yang belum terlihat dari kegiatan pembelajaran yang di susun 
oleh guru Fiqih MTs adalah penggunaan media berbasis IT. Tak satupun dari kegiatan pembelajaran yang di susun oleh guru MTs itu menggambarkan pada penggunaan media berbasis IT.Semua langkah-langkah kegiatan pembelajaran menggambarkan pada penggunaan media manual karena katakata yang mereka pilih adalah membaca referensi dan buku paket.Kalaupun ada yang memilih kata-kata seperti mengamati tayangan video atau membuka internet terkadang tidak dilakukan karena para guru belum dapat memahami betul tentang penerapan kurikulm 13

\section{Analisis Materi dalam Kurikulum}

\section{a. Analisis Materi}

Analisis materi dilakukan meliputi berbagai segi. Diantaranya: 1) Kesesuaian materi dengan tujuan pendidikan nasional dan institusi (apabila swasta); 2) Kesesuaian materi dengan standar kompetensi, kompetensi dasar, indikator, metode/media dan alokasi waktu; 3) Kesesuaian materi dengan perkembangan usia; 4) Kesesuaian materi dengan materi sebelum dan setelahnya; 5) Analisis isi, cakupan, kesahihan pikiran dan dalil serta redaksional materi; dan 6) Analisis terhadap jenis dan butir Evaluasi .

\section{b. Kesesuaian Materi dengan Tujuan Pendidikan Nasional ${ }^{13}$ dan Tujuan Institusi}

Materi yang ada di buku Ibadah/Mu'amalah di SMP/Mts Muhammadiyah sudah memenuhi tujuan pendidikan yang ada.Materi yang disajikan juga sudah memenuhi tujuan pendidikan nasional dan institusi siswa mempunyai akhlak yang mulia dan tertib dalam menjalankan ibadah dalam era globalisasi seperti saat ini.

c. Kesesuaian Materi dengan, Kompetensi Dasar, Indikator, Metode/Media dan Alokasi Waktu

Standar kompetensi dan kompetensi dasar sudah sesuai / sudah terpisah materi antara semester ganjil dan genap. Media yang digunakan dalam pembelajaran guru masih menggunakan metode lama yaitu metode ceramah yang memebuat siswa merasa bosan dalam KBM.Seharusnya pada era modern sekarang ini guru bisa menggunakan sistem belajar dalam bermain, metode berkelompok yang bisa siswa menerima pelajaran dengan diingat dan diterapkan dengan mudah dan menyenangkan. Alokasi waktu yang digunakan cukup yaitu $2 \times 4$ jam pelajaran.

d. KesesuaianMateri dengan Perkembangan Usia dan Kematangan

\section{Pikiran Siswa}

Dalam materi tersebut sudah sesuai dalam perkembangan usia dan kematangan pikiran siswa yang beranjak remaja yang bukan anak-anak lagi. Buku ini juga sangat bagus sudah ada kisah teladan yang bisa

${ }^{13}$ Tujuan pendidikan Nasional dan Institusi:

a. Meletakan dasar kecerdasan, pengetahuan, kepribadian, akhlak mulia serta keterampilan untuk hidup mandiri dan mengikuti pendidikan lebih lanjut.

b. Tumbuh, meningkat, dan terbentuknya anak didik menjadi siswa yang beriman dan bertaqwa kepada Allah SWT, berakhlak mulia, shaleh individual dan sosial. 
meningkatkankan cara berfikir siswa untuk meniru dan mencontoh kisah teladan bila perbuatannya baik dan tidak meniru dan mencontoh kisah teladan tersebut dan buku ini juga dilengkapi dengan gambar-gambar tata cara sholat dan wudhu pada bab 2 dan 4 sehingga siswa sangat mudah mempraktikannya dan dilengkapi kamus bahasa Indonesia. Setiap bab juga sudah ada gambaran atau ilustrasi, tetapi ada beberapa bab yang belum diberi gambaran atau ilustrasi missal.Pada kisah teladan sebaiknya juga diberikan gambaran atau ilustrasi agar bisa memperjelas dan murid bisa berimajinasi lebih.

\section{e. KesesuaianMateri dengan Materi Sebelum dan Setelahnya}

Dalam buku Pendidikan Ibadah/Mu'amalah MTs kelas 7 tema yang disajikan dari bab-perbab yaitu, bersuci dari najis dan hadas, wudhu dan tayammum, mandi wajib, sholat fardhu, sholat berjama'ah dan munfarid, sholat jama dan qashor, sholat jum'at, khutbah jum'at, sholat sunnah dan sujud. Menurut urutannya sudah sesuai ( bertahap ).

\section{E. Pengembangan Kurikulum}

Untuk mengembangkan indikator pembelajaran setiap guru seharusnya berpedoman pada Taksonomi Bloom karena di dalam taksonomi Bloom tersebut level-level ranah kemampuan baik itu kemampuan kognitif, afektif maupun kemampuan psikomotor sudah tersusun secara sistematis dan terdapat banyak pilihaan kosa kata yang sesuai dengan tuntutan KI-KD. Hal ini menjadi suatu tuntutan yang harus dipenuhi oleh seorang guru karena diantara prinsip pengembangan silabus adalah sistematis, relevan, dan memadai.

Agar seorang guru yang mengajar dapat mengevaluasi pembelajaran yang sesuai dengan keadaan siswa, media, sarana dan prasarana serta lingkungan sekolah maka seorang guru harus melakukan metode evaluasi pembelajaran yang bervariasi.

Di zaman teknologi yang moderen saat ini sudah selayaknya seorang guru sudah memiliki kemampuan untuk menggunakan media berbasis IT seperti kemampuan menggunakan laptop, kemampuan menggunakan internet dan sejenisnya.Hal ini sangat bermanfaat bagi seorang guru karena disamping untuk mempermudah guru dalam menggali informasi yang beragam juga lebih meringankan tugas guru jauh lebih efektif dan efesien serta tujuan pembelajaran dapat lebih mencapai hasil yang maksimal.

\section{F. Kesimpulan}

Demikian paparan tentang kajian kurikulum 2013 pada mata pelajaran fiqih di Madrasah Tsanawiyah.Penulis menyadari bahwa dalam penulis makalah ini masih banyak terdapat kekurangan dan kesalahan.Oleh karena itu penulis mengharapkan kritik dan saran yang bersifat membangun sangat penulis harapkansebagai perbaikan penulisan makalah berikutnya. 


\section{DAFTAR PUSTAKA}

Abdul Majid, Perencanaan Pembelajaran (Bandung: Remaja Rosda Karya, 2008)

B. Uno, Hamzah, Orientasi dalam Psikologi Pembelajaran (Jakarta:PT Bumi Aksara, 2006.

Dede Rosyada, Paradigma Pendidikan Demokratis: sebuah moel pelibatan Masyarakat dalam penyelenggaraan Pendidikan (Jakarta: Kencana, 2004)

E, Mulyasa, Guru dalam Implementasi Kurukulum 2013 (Bangdung: PT Remaja Rosdakarya Offset, 2014),

Fadlilah, Implementasi Kurikulum 2013 dalam Pembelajaran SD/MI, SMP/MTs \& SMA/MA

Hamzah B. Uno, Orientasi dalam Psikologi Pembelajaran (Jakarta:PT Bumi Aksara, 2006.

Peraturan Menteri Agama Republik Indonesia Nomor 2 Tahun 2008 Tentang Standar Kompetensi Lulusan Dan Standar Isi Pendidikan Agama Islam Dan Bahasa Ara Di Madrasah

Peraturan Menteri Agama Republik Indonesia Nomor 000912 tahun 2013 tentang Kurikulum 2013 Mata Pelajaran PAI dan B.Arab

Peraturan Menteri Agama Republik Indonesia Nomor 54 Tahun 2013 Tentang Standar Kompetensi Lulusan Pendidikan dasar Dan Menengah

Surya,Muhammad, Psikologi Pembelajran dan Pengajaran (Bangdung: Pustaka Bani Quraisy, 2004)

Suryosubroto, B, Proses Belajar Mengajar di Sekolah (Jakarta: Rinneka Cipta, 2009 